ORIGINAL ARTICLE

\title{
Survey of social wasps (Hymenoptera, Vespidae, Polistinae) in Amazon rainforest fragments in Acre, Brazil
}

\author{
Bruno GOMES ${ }^{1}$, Samilla Vanessa de Lima KNIDEL ${ }^{1}$, Herólison da Silva MORAES ${ }^{1}$, Marjorie da SILVA \\ 1 Universidade Federal do Acre, Centro de Ciências Biológicas e da Natureza, Rodovia BR 364, Km 04, Distrito Industrial, 69915-900, Rio Branco - AC, Brazil, \\ 2 Universidade Estadual Paulista "Júlio de Mesquita Filho", Instituto de Biociências, Letras e Ciências Exatas, Rua Cristóvão Colombo, 2265, Jardim Nazareth, 15054- \\ 000, São José do Rio Preto - SP, Brazil. \\ Corresponding author: marjoriebio@gmail.com
}

\section{ABSTRACT}

The State of Acre, in the southwestern Brazilian Amazon, harbors high biodiversity and a high degree of endemisms. Nevertheless, there are few studies on the diversity of social wasps occurring in this region. This study presents a list of social wasps (Hymenoptera, Vespidae, Polistinae) collected actively with attractive bait in three rainforest fragments in Acre. A total of 758 wasps belonging to 11 genera and 36 species were collected. Nineteen species were new distribution records for Acre and three others were new records for Brazil. Based on our results, further investigations should lead to a significant increase in Polistinae diversity in this region, producing information for biogeographic studies and management of natural areas.

KEYWORDS: distribution records, Neotropical Region, swarm-founding wasps, Western Amazon

\section{Levantamento de vespas sociais (Hymenoptera, Vespidae, Polistinae) em fragmentos de floresta Amazônica no Acre, Brasil}

\section{RESUMO}

O estado do Acre é parte da Amazônia Ocidental brasileira, uma área que abriga uma grande biodiversidade e alto grau de endemismos. Contudo, poucos estudos investigaram a diversidade de vespas sociais nesta região. Este trabalho apresenta os resultados de uma amostragem de vespas sociais (Hymenoptera,Vespidae, Polistinae) em três fragmentos de floresta primária no estado do Acre. As vespas foram coletadas ativamente com o uso de solução atrativa. Um total de 758 vespas, pertencentes a 11 gêneros e 36 espécies, foi amostrado, sendo 19 dessas espécies novos registros de distribuição para o Acre e três novos registros para o Brasil. Nossos resultados indicam que novas investigaçóes devem levar a um aumento significativo da diversidade de espécies de vespas Polistinae conhecida para a região. Nosso estudo produziu subsídios de grande utilidade para estudos biogeográficos e fornece informações importantes para a tomada de decisões sobre o manejo de áreas naturais.

PALAVRAS-CHAVE: registro de espécies, Região Neotropical, vespas enxameadoras, Amazônia Ocidental 


\section{INTRODUCTION}

Tropical forests represent only $7 \%$ of biomes of the planet, however, these ecosystems host more than half of all known species of plants and animals (Wilson 1988; May 2010; Miranda et al. 2012). The Brazilian Amazon rainforest has one of the greatest biodiversities in the world, including the greatest diversity of social wasps (Silveira 2002; Somavilla et al. 2014; Barbosa et al. 2016). The western Amazon (which includes parts of Bolivia, Colombia, Ecuador, Peru, and western Brazil) is one of the most biodiverse regions of the planet for many taxa (Brown 1977, 1991; Calouro 1999; Carpenter and Marques 2001; Ceballos and Ehrlich 2006; Carvalho and Esposito 2010; Barbosa et al. 2016). The region maintains large areas of intact tropical forest and stable climate conditions, which, combined with richer soils originated from Andean sediments, is likely related to the west-east diversity gradient that has been found for some groups of Amazonian organisms, such as trees and mammals (Ceballos et al. 2005; Hoorn et al. 2010; Cheng et al. 2013). Moreover, it is an area close to the Andes of Peru and Bolivia, regions known for endemic species of different groups of organisms (LöwenbergNeto and Carvalho 2009; SigristandCarvalho2009; Haseyama and Carvalho 2011).

Polistinae is the most diverse group among the social wasps, with more than 900 species described. The subfamily is divided in the tribes Ropalidiini, Polistini, Mischocyttarini and Epiponini. Except for Ropalidiini, the other tribes are represented in Brazil. Polistes Latreille, Mischocyttarus de Saussure, and the 19 genera of Epiponini compose the Brazilian fauna of wasps, totalizing about 300 species, of which 104 are endemic (Carpenter and Marques 2001; Carpenter 2004; Noll 2013). The states of Minas Gerais, Sáo Paulo and Bahia concentrate more than half of all social wasp surveys carried out in Brazil to date (Barbosa et al. 2016). On the other hand, no published records on social wasp fauna exist so far for nine of the 27 Brazilian states (Barbosaet al. 2016). In the Amazon region the low density of researchers and complex logistics result in comparatively fewer biodiversity surveys, usually concentrated near the large urban centers of the region, that are more accessible and where most specialists work, especially in the eastern Amazon region.

The Acre state is located in the southwestern Brazilian Amazon and covers a territory of $164.123 \mathrm{~km}^{2}$ (IBGE 2014) with more than $90 \%$ of its area still covered by primary forest (Salimon and Brown 2000). Several studies have demonstrated the existence of areas with a high biodiversity and high degree of endemism in this state (Souza et al. 2003) for plants (Prance 1973; Silveira et al.1997; Goldenberg and Meirelles 2011), mammals (Calouro 1999), birds (Haffer 1987; Whitaker and Oren 1999; Guilherme 2001; Guilherme and Borges 2011), amphibians (Lima et al.2007), some insect orders (Brown
1991), including ants (Oliveira et al. 2009; Miranda et al. 2012), paper wasps (Morato 2001), lepidopterans (Brow, 1977), coleopterans (Vaz-de-Melo 1999), dipterans (Carvalho and Esposito 2010) and other arthropods, such as Opiliones (Villarreal-Manzanilla and Pinto-Da-Rocha 2006). Yet, very little is known about the diversity of social wasps in this part of the Amazon, since only two surveys carried out in Acre included social wasps (Richards 1978; Moratoet al.2008).

Insect samplings are usually highly underestimated (Troudet et al. 2017), although this group represents around $80 \%$ of all living animals (Smithsonian 2017). In this way, species inventories are important tools to improve the basic knowledge on species distribution and abundance in little known and highly biodiverse regions, such as the Amazon, and constitutes valuable information to guide conservation policies. In this study, we present the results of a survey of social wasps (subfamily Polistinae) carried out in three forest fragments in the southeastern part of the state of Acre.

\section{MATERIALS AND METHODS}

\section{Study areas}

Three fragments of Amazon rainforest, close to the city of Rio Branco in the east of the state of Acre, Brazil (Figure 1), were sampled. Reserva Florestal Humaitá (HU) is located in the municipality of Porto Acre (9 44'44"S, 67\%40'60”W), with an area of 3.665ha and an average altitude of $198 \mathrm{~m}$. Fazenda Experimental Catuaba (CA) is located in the municipality of Senador Guiomard (1004’40"S, 67³7’35”W), with an area of 1.281 ha and $191 \mathrm{~m}$ of average altitude. Parque Zoobotânico (PZ) is the zoobotanical park of the Federal University of Acre (Universidade Federal do Acre) (9 $57^{\circ} 16^{\prime \prime} \mathrm{S}$, $\left.67^{\circ} 52^{\prime} 17^{\prime \prime} \mathrm{W}\right)$, and is located in an urban region of the capital city Rio Branco, with an average altitude of $165 \mathrm{~m}$ and an area of 100 ha (Storck-Tononet al. 2013).

The region where the three areas are located is characterized by open forest with the presence of bamboos (locally known as tabocais), common in the Andean region in Peru, and palm trees (Silveira 2005). The tabocais are dense, with a high density of lianas and bamboos, and an open canopy with an average height of 20-40 m (Daly and Silveira 2008). The predominant type of soil in the region is latosol and the landscape is slightly hilly (Daly and Silveira 2008).

The average annual temperature varies between 22 and $24^{\circ} \mathrm{C}$. Lowest temperatures occur in August (about 12 to $14^{\circ} \mathrm{C}$ ) (Mesquita and Paiva 1995; Mesquita1996). Average annual rainfall is $1944 \mathrm{~mm}$, varying between 1566 and 2425 $\mathrm{mm}$. The climate is tropical wet, with well-defined hot/dry (winter) and hot/rainy (summer) seasons. The rainy period occurs from October to April and the driest period from June to August. May and September are transitional months between seasons (Duarte 2005). 


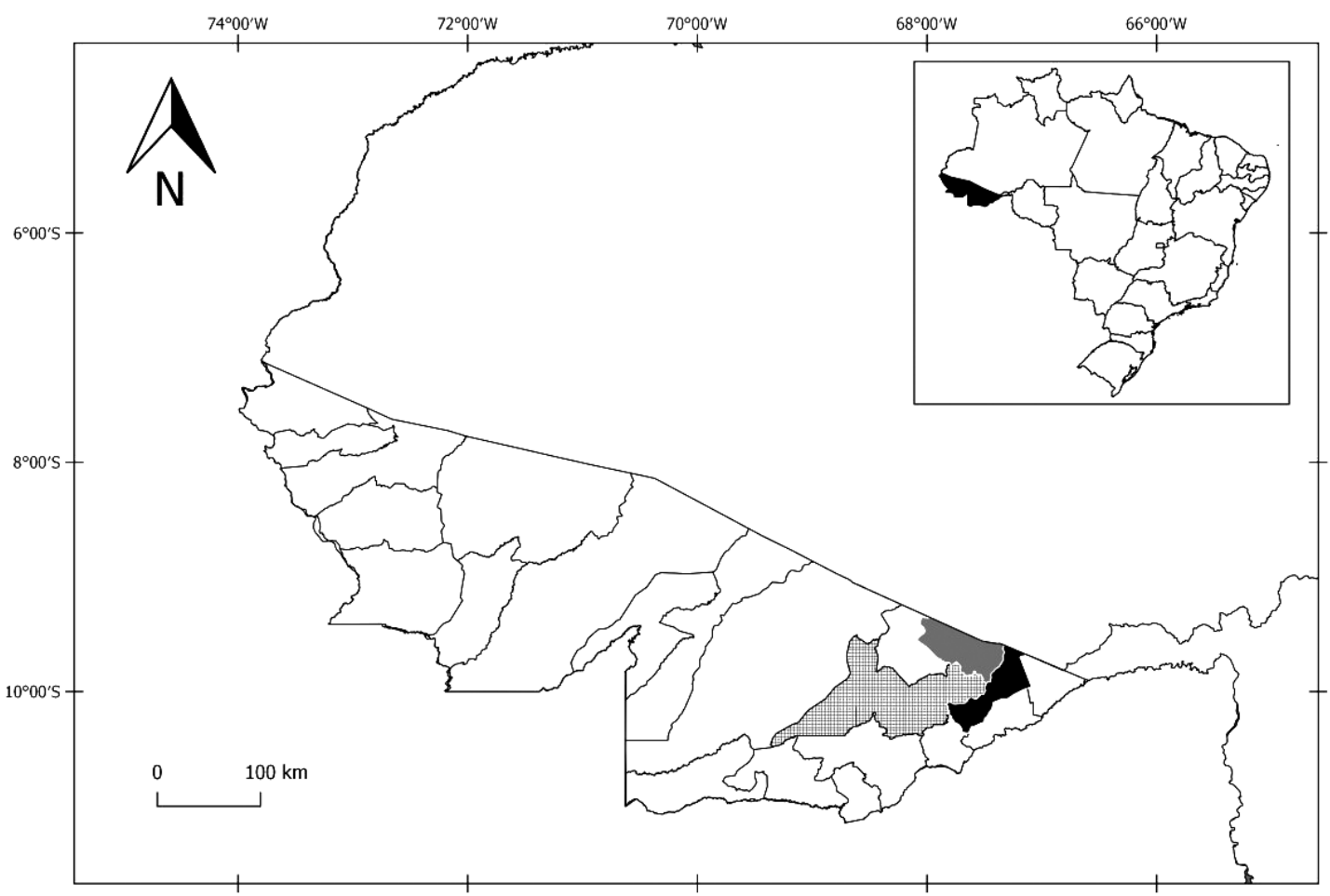

Figure 1. Map of Acre state showing the locations of the municipalities of Porto Acre (dark grey), Rio Branco (light grey) and Senador Guimard (black), where the three study sites were located. The inset shows Acre state (black) in the map of Brazil.

\section{Sampling method}

Wasps were sampled from April to November of 2014 along previously open trails in the forest. Specimens were attracted by a solution sprayed on the vegetation and collected actively using an entomological net (adapted from Noll and Gomes 2009). A comparison among sampling techniques showed this to be the most effective, especially for social wasps, as it rendered a greater richness and abundance with lower sampling effort (Noll and Gomes 2009). To apply the attractant liquid in vegetation, we used a costal sprayer $(5 \mathrm{~L})$, which was filled with a solution containing $50 \mathrm{~g}$ salt and 200 g sugar per liter of water.

In each study area, sampling occurred on eight $100-\mathrm{m}$ trails drawn linearly, distant approximately 20 meters from each other, on a previously open track. Spraying of the attractive solution was carried out at five points on each trail, separated by $20 \mathrm{~m}$ from each other. At each point we applied an average of $500 \mathrm{ml}$ solution on an area of $4 \mathrm{~m}^{2}$ of vegetation. The liquid was reapplied every two hours. Later, the points were observed individually for ten minutes between 14:00 and 17:00 and wasps were collected. Collection time totalled 60 hours and sampling distance totalled $2.4 \mathrm{~km}$ overall in the three study areas. The specimens were collected under IBAMA/SISBio permit nr. 43174-1.

\section{Species preservation and data analysis}

After collection, specimens were killed by putting them in a container with ethyl acetate and posteriorly stored in microtubes containing ethanol absolute. Wasps were identified with the dichotomous identification keys proposed by Richards (1978), Cooper (2000) and Carpenter and Marques (2001). Part of the material was identified by specialists and deposited in the zoological collection of the Museu Paraense Emílio Goeldi, in Belém, Pará state, Brazil, and the zoological collection of Universidade Federal do Acre, in Rio Branco, Acre state, Brazil.

\section{RESULTS}

A total of 758 social wasp specimens were collected, representing 36 species and 11 genera (Table 1 ). We collected 389 specimens from 21 species and seven genera in PZ, 162 specimens from 16 species and seven genera in CA, and 207 specimens from 26 species and eight genera in $\mathrm{HU}$, where the greatest diversity was recorded (Table 1). Regarding species composition, only eight species were sampled in all three areas. PZ and $\mathrm{HU}$ shared five species, while four species were collected in $\mathrm{HU}$ and $\mathrm{CA}$, and only two species were collected only in PZ and CA. HU presented the largest number of exclusive species (9), followed by PZ (6) and CA (2) (Figure 2). 
Agelaia was the most abundant genus, collected more frequently in CA $(83 \%$ of all sampled individuals in this area) and HU (77,5\%) while in PZ, Angiopolybia was most abundant (43\%). Polybia was the richest genus for all study areas, followed by Agelaia (Table1). It is possible that the large number of Angiopolybia zischkai (166) individuals sampled in
PZ was due to the presence of a nest near the collection point, although no nest was observed during sampling.

From the 36 species sampled, 19 were new records for Acre state (Table 1) and three of them - Agelaia bazeae, $A$. pleuralis and Polybia simillima - were recorded for the first time in Brazil (Figure 3).

Table 1. Species richness, abundance and number of exclusive species of social wasps (Polistinae) collected in Parque Zoobotânico (PZ), Fazenda Experimental Catuaba (CA) and Reserva Florestal Humaitá (HU) in the state of Acre, Brazil.' new record for Acre, ${ }^{2}$ new record for Brazil.

\begin{tabular}{|c|c|c|c|c|}
\hline \multirow{2}{*}{ Species } & \multicolumn{4}{|c|}{ Number of specimens } \\
\hline & $\mathrm{PZ}$ & CA & $\mathrm{HU}$ & Total \\
\hline \multicolumn{5}{|l|}{ Polistini } \\
\hline Polistes pacificcus liliaciosus Saussure ${ }^{1}$ & 5 & - & - & 5 \\
\hline Polistes deceptor Schulz & - & - & 2 & 2 \\
\hline \multicolumn{5}{|l|}{ Mischocyttarini } \\
\hline Mischocyttarus carbonarius (Saussure, 1854)' & 1 & - & - & 1 \\
\hline Mischocyttarus flavicans (Fabricius, 1804)'1 & 2 & - & - & 3 \\
\hline Mischocyttarus labiatus (Fabricius, 1804) & 11 & - & 3 & 14 \\
\hline Mischocyttarus metathoracicus (Saussure, 1854)' & - & 1 & 2 & 3 \\
\hline Mischocyttarus surinamensis (Saussure, 1854) & - & - & 1 & 1 \\
\hline Mischocyttarus synoecus Richards, $1940^{1}$ & 1 & - & 10 & 11 \\
\hline Mischocyttarus group prominulus sp. & - & - & 2 & 2 \\
\hline \multicolumn{5}{|l|}{ Epiponini } \\
\hline Agelaia pleuralis Cooper, $2000^{2}$ & 51 & 2 & 2 & 55 \\
\hline Agelaia angulata (Fabricius, 1804) & - & 17 & 35 & 52 \\
\hline Agelaia baezae (Richards, 1943)² & - & - & 1 & 1 \\
\hline Agelaia brevistigma (Richards, 1978)' & - & - & 1 & 1 \\
\hline Agelaia fulvofasciata (DeGeer, 1773) & 2 & 68 & 48 & 118 \\
\hline Agelaia myrmecophila (Ducke, 1905) & 9 & 23 & 44 & 76 \\
\hline Agelaia pallipes cuzcoensis (Schrottky, 1911) & 40 & - & 1 & 41 \\
\hline Agelaia testacea (Fabricius, 1804) & 10 & 25 & 30 & 65 \\
\hline Angiopolybia obidensis (Ducke, 1904)'1 & - & 3 & - & 3 \\
\hline Angiopolybia zischkai Richards, $1978^{1}$ & 166 & - & - & 166 \\
\hline Brachygastra augusti (Saussure, 1854) & - & - & 4 & 4 \\
\hline Brachygastra propodealis Bequard, $1942^{1}$ & - & - & 1 & 1 \\
\hline Charterginus fulvus Fox, $1904^{1}$ & - & - & 1 & 1 \\
\hline Leipomeles dorsata (Fabricius, 1804)' & 3 & 2 & 1 & 6 \\
\hline Parachartergus flavofasciatus (Cameron, 1906) ${ }^{1}$ & - & 6 & 1 & 7 \\
\hline Polybia catillifex Moebius, $18566^{1}$ & 11 & - & - & 11 \\
\hline Polybia dimidiata (Olivier, 1791)'1 & 8 & 2 & - & 10 \\
\hline Polybia eberhardae Cooper, $1993^{1}$ & - & - & 2 & 2 \\
\hline Polybia gorytoides Fox, $1898^{1}$ & 3 & 2 & 1 & 6 \\
\hline Polybia jurinei Saussure, 1854 & 1 & 1 & - & 2 \\
\hline Polybia liliacea (Fabricius, 1804) & 1 & - & 4 & 5 \\
\hline Polybia rejecta (Fabricius, 1798) & 3 & 1 & 4 & 8 \\
\hline Polybia rufitarsis Ducke, 19041 & - & 2 & 2 & 4 \\
\hline Polybia simílima Smith, $1862^{2}$ & 58 & 4 & 1 & 63 \\
\hline Polybia striata (Fabricius, 1787) & 1 & - & 3 & 4 \\
\hline Pseudopolybia vespiceps (Saussure, 1863)' & 1 & - & - & 1 \\
\hline Synoeca virgínea (Fabricius, 1804) & - & 3 & - & 3 \\
\hline Richness & 21 & 16 & 26 & 36 \\
\hline Abundance & 389 & 162 & 207 & 758 \\
\hline Exclusive species & 6 & 2 & 9 & 17 \\
\hline
\end{tabular}




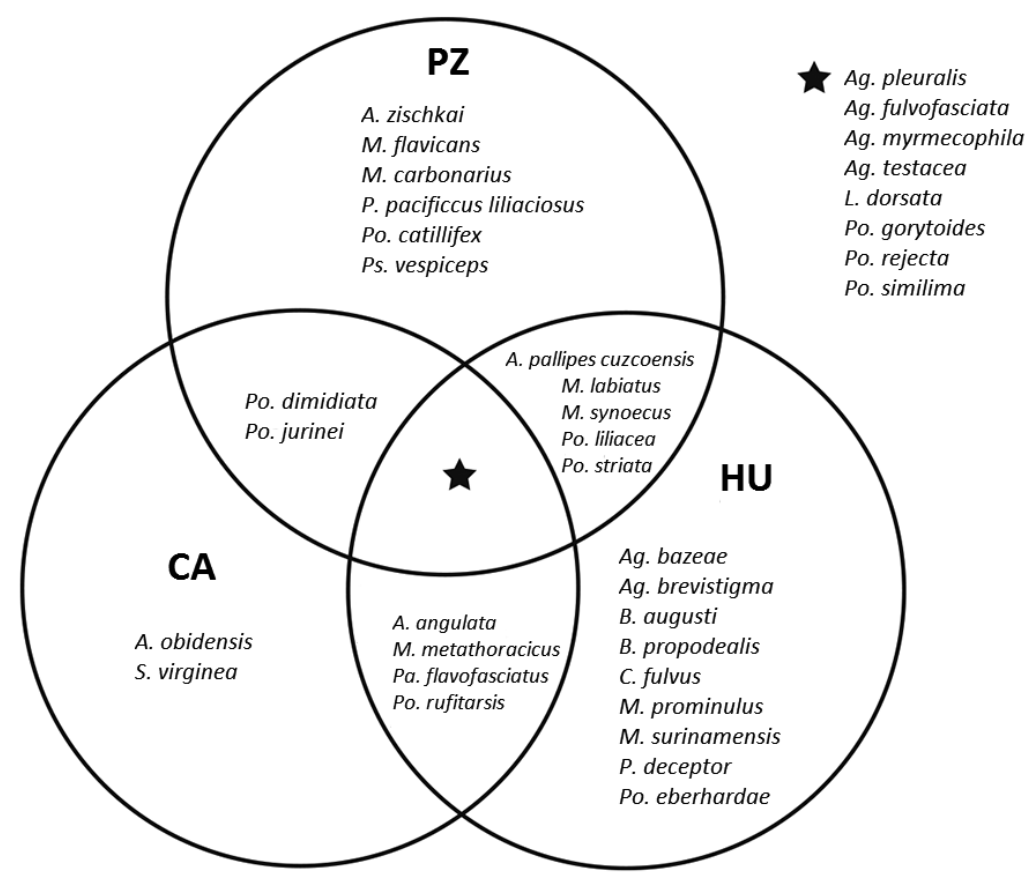

Figure 2. Venn Diagram showing the exclusive and shared species of Polistinae among the three study areas in the state of Acre, Brazil. The asterisk indicates species that were present in all three areas. CA, Catuaba; HU, Humaitá; PZ, Parque Zoobotânico; Ag, Agelaia; An, Angiopolybia; B. Brachygastra; C, Charterginus, L, Leipomeles; M, Mischocyttarus; P, Polistes; Pa, Parachartergus; Po, Polybia; Ps, Pseudopolybia; S. Synoeca.

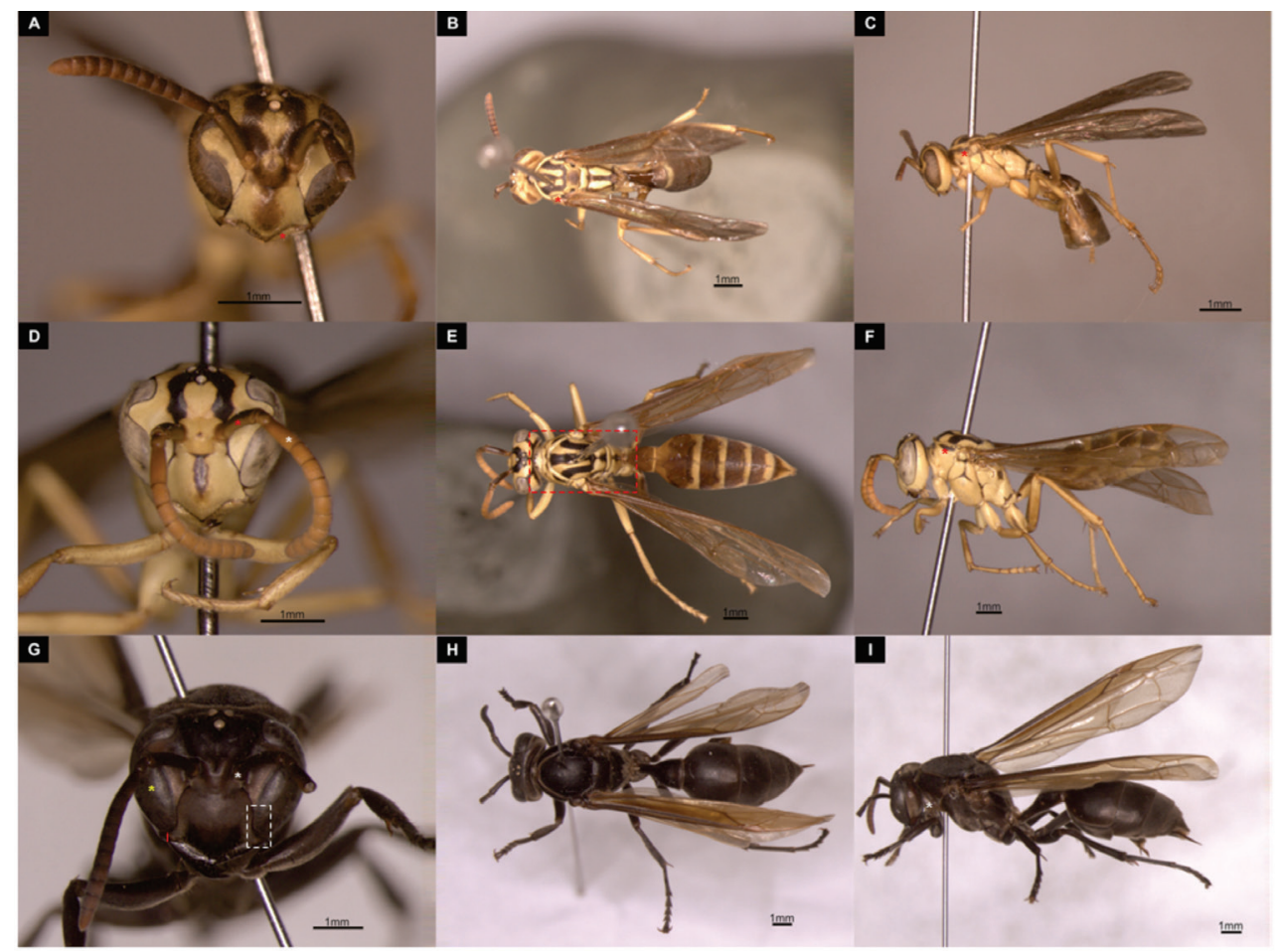

Figure 3. Frontal, dorsal and lateral view of species sampled in southeastern Acre as new records for Brazil. A-C, Agelaia baezae; D-F, Agelaia pleuralis; G-I, Polybia similima. Ventral margin of clypeus reddish tinged (A); tegula less accuted (B); pronotal keel broader (C). Antenna with scape black above, yellow beneath and pedicel and flagellum ferruginous (D); dorsum with extensive brown or black maculation (red rectangle - E); lamellate anterior margin of pronotum not markedly sinuate below fovea (F). Eyes bare, malar space very short, clypeus in contact with the eyes for a distance greater the height of antennal sockets (white rectangle - G); pronotal keel distinct on the shoulders, proeminence in front of the fovea strong but not sharp (I). Structures are indicated by asterisks. This figure is in colour in the electronic version. 


\section{DISCUSSION}

Our results represent a significant addition to the known diversity of social wasps in the eastern Amazon, of which only scarce information was available until now. From the 19 species recorded for the first time in Acre, the majority was already known to occur in the Amazon, mainly in the states of Amapá, Amazonas and Pará. They were also recorded in Peru, which borders with Acre, so their presence in this state was expected. Similarly, the records of Polybia dimidiata, Leipomeles dorsata and Pseudopolybia vespiceps in Acre was not surprising, because they are widespread in Brazil and other countries in South America. However, the record of Polistes deceptor extends its range of distribution significantly, once there were only two records for this species before: in Pará (the holotype) and São Paulo state (Richards 1978; IUNH 2017) in southeastern Brazil. The same can be said of Polybia catillifex, previously registered only in the states of Amazonas, Rio de Janeiro and São Paulo. For Angiopolybia zischkai and Brachygastra propodealis, there was only one previous record for Brazil (Gomes 2013; Barbosa et al., 2016), in the state of Rondônia, also located in the western Amazon region.

Regarding the three species sampled for the first time in Brazil, they had their distribution range significantly extended. Agelaia bazeae had been previously recorded in Ecuador, Colombia and Panama, while $A$. pleuralis had records in Costa Rica and Colombia (Richards 1978; Cooper 2000; IUNH 2017). Polybia simillima was previously registered in Belize, Colombia, Costa Rica, Ecuador, Guatemala, Honduras, Mexico, Panama and Venezuela (Richards 1978; IUNH 2017). These new distribution records shed a light on how little we know of a potentially very high but still unexplored species richness of social wasps in the western Amazon region. Despite the highest diversity of social wasps being found in the Amazon region, our findings suggest that many species of the Amazon wasp fauna have been collected only in other biomes.

The genera Agelaia and Angiopolybia were the most abundant, an expected result as they are present in all inventories of social wasps in Amazonian rainforest (Richards 1978; Barbosa et al. 2016). Mischocyttarus is the genus with the highest number of species of social wasps (around 240), of which 117 occur in Brazil (Carpenter and Marques 2001), yet in our samples Polybia was the most diverse genus. Polybia is the genus with the largest number of species within Epiponini.

In a survey of wasps from Parque Nacional da Serra do Divisor (PNSD), also in Acre, a total of 20 species of Polistinae were sampled (Morato et al. 2008). We sampled 15 more species than the latter authors, and only six (Mischocyttarus labiatus, Agelaia angulata, A. fulvofasciata, A. myrmecophyla, Polybia rejecta and Synoeca virginea) were also sampled by them. One possible explanation for the difference in species composition between the two surveys is the difference in altitude between the study sites. PNSD is hilly to mountainous, with altitudes of 200 up to $580 \mathrm{~m}$ (Brazil 1977). In addition, different sampling methods were used. In a survey of social wasps in the state of Pará, Brazil (eastern Amazon) that compared different sampling methods, the active search method was far more efficient than Malaise traps (Silveira 2002). Likewise, Noll and Gomes (2009) collected the greatest number of species and individuals of social wasps using the active search method combined with an attractive solution.

The Amazon region has the highest diversity of Polistinae species (Richards 1978; Carpenter and Marques 2001; Silveira 2002; Barbosa et al. 2016). In the Brazilian Amazon, 20 genera and more than 200 species have been recorded, which represents about two thirds of the Brazilian diversity of social wasps (Silveira 2002). Currently 125 species have been reported for the state of Amazonas, despite only four studies on social wasps having been carried out in the state to date (Barbosa et al. 2016), which clearly indicates that the the diversity of wasps in the region is still vastly underestimated.

\section{CONCLUSIONS}

We recorded 36 species of social wasps in three forest fragments in the southeast of Acre state, in the southwestern Brazilian Amazon. Polybia was the most species-rich genus in the overall sample, while Agelaia and Angiopolybia were the most abundant. Nineteen species were first records for Acre. These new records significantly increased the range for some species and filled distribution gaps for others. Our records of Angiopolybia zischkai and Brachygastra propodealis represented the second record for each species in Brazil. We also produced the first records of Agelaia baezae, A. pleuralis and Polybia simillima for Brazil. There was relatively low species overlap among the three sampled fragments, as well as with the species sampled in the higher-altitude area of Parque Nacional da Serra do Divisor, in eastern Acre. These differences in species composition reinforce the need for more research on the biodiversity of swarm-founding wasps in the western part of the Brazilian Amazon. The results obtained in this study indicate that further investigations should significantly increase the species diversity of wasps in this region and add more information to the knowledge of Polistinae diversity.

\section{ACKNOWLEDGEMENTS}

We would like to thank Dr. Orlando T. Silveira for the identification of Mischocyttarus species, Raduan Alexandre Soleman, Me. Rogério Botion Lopes and Me. Yuri Campanholo Grandinete for confirming some identifications, and Prof. Dr. Elder F. Morato and Prof. Dr. Lisandro J.S. Vieira for the support in the Universidade Federal do Acre. We also thank to Dr. Johan Billen for the help with English revision. Finally, the authors thank the Comissão de Aperfeiçoamento de Pessoal do Nível Superior (Capes) for the financial support. 


\section{REFERENCES}

Barbosa, B.C.; Detoni, M.; Maciel, T.T.; Prezoto, F. 2016. Studies of social wasp diversity in Brazil: Over 30 years of research, advancements and priorities. Sociobiology, 63: 858-880.

Brasil. 1977. Projeto RADAMBRASIL: levantamento de recursos naturais. Vol.13. Folhas SB/SC. 18. Javari/Contamana. Departamento Nacional da Produçáo Mineral, Rio de Janeiro, 413p.

Brown, K.S.Jr. 1977.Centros de evolução, refúgios quaternários e conservação de patrimônios genéticos na região neotropical: padrões de diferenciação em Ithomiinae (Lepidoptera: Nymphalidae). Acta Amazonica, 7: 75-137.

Brown K.S. Jr. 1991. Conservation of Neotropical environments: insects as indicators. In: Collins, N.M.; Thomas, J.A. (Ed.), The conservation of insects and their habitats. Academic Press, London. p.349-404.

Calouro, A.M. 1999. Riqueza de mamíferos de grande e médio porte do Parque Nacional da Serra do Divisor (Acre, Brasil). Revista Brasileira de Zoologia, 16: 195-213.

Carpenter, J.M. 2004. Synonymy of the genus Marimbonda Richards, 1978, with Leipomeles Möbius, 1856 (Hymenoptera: Vespidae: Polistinae), and a new key to the genera of paper wasps of the New World. American Museum Novitates, 3456: 1-16.

Carpenter, J.M.; Marques, O.M. 2001. Contribuição ao estudo de vespideos do Brasil (Insecta, Hymenoptera, Vespoidea, Vespidae), v.2, version o 1.0. 1 CDROM. Universidade Federal da Bahia, Cruz das Almas.

Carvalho, F.S.; Esposito, M.C. 2010. A New Species of Bricelochlorops Paganelli and the first record of Urubambina rufa (Duda) (Diptera: Chloropidae) from Brazil. Neotropical. Entomology, 39: 742-745.

Ceballos, G.; Ehrlich, P.R. 2006. Global mammal distributions, biodiversity hotspots and conservation. Proceedings of the National Academy of Sciences of USA, 103: 19374-19379.

Ceballos, G.; Ehrlich, P.R.; Soberon, J.; Salazar, I.; Fay, J.P. 2005. Global mammal conservation: what must we manage? Science, 309: 603-607.

Cheng, H.; Sinha, A.; Cruz, F.W.; Wang, X.; Edwards, R.L.; d'Horta, F.M.; Ribas, C.C.; Vuille, M.; Stott, L.D.; Auler, A.S. 2013. Climate change patterns in Amazonia and biodiversity. Nature Communications, 4: 1411.

Cooper, M. 2000. Five new species of Agelaia Lepeletier (Hym.,Vespidae, Polistinae) with a key to members of the genus, new synonymy and notes. Entomologist's Monthly Magazine, 136: $177-197$.

Daly, D.C.; Silveira, M. 2008.Primeiro catálogo da flora do Acre, Brasil / First catalogue of flora of Acre, Brazil. EDUFAC,Rio Branco, 555p.

Duarte, A.F. 2005. Variabilidade e tendência das chuvas em Rio Branco, Acre, Brasil. Revista Brasileira de Metereologia, 20: 37-42.

Finer, M.; Jenkins, N.C.; Pimm, S.L.; Keane, B.; Ross, C. 2008.Oil and gas projects in the western Amazon: threats to wilderness, biodiversity, and Indigenous Peoples. PLoS ONE, 3: e2932.

Guilherme, E. 2001. Comunidade de aves do Campus e Parque Zoobotânico da Universidade Federal do Acre, Brasil. Tangara, 1: $57-73$.
Guilherme, E.; Borges, S.H. 2011. Ornithological records from a campina/campinarana enclave on the upper Jurua River, Acre, Brazil. Wilson Journal of Ornithology, 123: 24-32.

Goldenberg, R.; Meirelles, J. 2011. A new species of Graffenrieda (Merianieae, Melastomataceae) with a calyptrate calyx. Systematic Botany, 36: 119-123.

Gomes, B. 2013. Diversidade de vespas sociais (Vespidae, Polistinae) na região norte de Rondônia e relação dos ciclos ambientais abióticos sobre o forrageio. Doctoral thesis, Universidade de São Paulo, Ribeirão Preto, São Paulo. 55p.

Haffer, J. 1987. Biogeography of neotropical birds. In: Whitmore, T.C.; Prance, G.T. (Ed.). Biogeography and Quaternary History in Tropical America. Clarendon Press, Oxford, p.105-150.

Haseyama, K.L.F.; Carvalho, C.J.B. 2011. Padrões de distribuição da biodiversidade Amazônica: Um ponto de vista evolutivo. Revista da Biologia, Vol. Esp. Biogeografia: 35-40.

Hoorn, C.; Wesselingh, F.P.; terSteege, H.; Bermudez, M.A.; Mora,A.; Sevink, J.et al. 2010. Amazonia through time: Andean uplift, climate change, landscape evolution and biodiversity. Science, 330: 927-931.

IBGE. 2014. Instituto Brasileiro de Geografia e Estatística. Área Territorial Brasileira. (http://www.ibge.gov.br/home/geociencias/ areaterritorial/principal.shtm). Accessed on 07/01/2014.

IUNH. 2017. Natural History Laboratory, Ibaraki University and World Association for the Study of Paper Wasps Japan. Checklist and/or Catalog of Social Wasps. (http://iunh2.sci.ibaraki.ac.jp/ wasp/Epiponini/epiponini.htm). Accessed on 10/06/2017.

Löwenberg-Neto, P.; Carvalho, C.J.B. 2009. Areas of endemism and spatial diversification of the Muscidae (Insecta: Diptera) in the Andean and Neotropical regions. Journal of Biogeography, 36: 1750-1759.

Lima, A.P.; Sanchez,D.E.A.; Souza, J.R.D. 2007. A new Amazonian species of the frog genus Colostethus (Dendrobatidae) that lays its eggs on undersides of leaves. Copeia, 2007: 114-122.

May, R. 2010. Tropical arthropod species, more or less? Science, 329: 41-42.

Mesquita, C.C.1996. O clima do Estado do Acre. Secretaria de Estado de Ciência, Tecnologia e Meio Ambiente - SECTMA, Rio Branco, 53p.

Mesquita, C.C.; Paiva, R.A. 1995. Estudos básicos das precipitaçôes do Acre. Secretaria de Estado de Planejamento, Rio Braco, 148p.

Miranda, P.N.; Oliveira, M.A.; Baccaro, F.B.; Morato, E.F.; Delabie, J.H.C. 2012. Check list of ground-dwelling ants (Hymenoptera: Formicidae) of the eastern Acre, Amazon, Brazil. Check List, 8: 722-730.

Morato, E.F. 2001. Ocorrência de Aglaeca erulea Lepeletier \& Serville (Hymenoptera, Apidae, Apini, Euglossina) no Estado do Acre, Brasil. Revista Brasileira de Zoologia, 18: 1031-1034.

Morato, E.F.; Amarante, S.T.; Silveira, O.T. 2008. Avaliação ecológica rápida da fauna de vespas (Hymenoptera: Aculeata) do Parque Nacional da Serra do Divisor, Acre, Brasil. Acta Amazonica, 38: 789-797.

Nadia, T. de L.; Machado, I.C.; Lopes, A.V. 2007. Fenologia reprodutiva e sistema de polinização de Ziziphus joazeiro Mart. (Rhamnaceae): atuação de Apis melifera e de visitantes florais 
autóctones como polinizadores. Acta Botânica Brasilica, 21: 835-845.

Noll, F.B. 2013. "Marimbondos": a review on the neotropical swarmfounding polistines. Sociobiology, 60: 347-354.

Noll, F.B.; Gomes, B. 2009. An improved bait method for collecting hymenoptera, especially social wasps (Vespidae: Polistinae). Neotropical Entomology, 38: 477-481.

Oliveira, M.A.; Della Lucia, T.M.C.; Marinho, C.G.S.; Delabie, J.H.C.; Morato, E.F. 2009. Ant diversity in an area of the Amazon Forest in Acre, Brazil. Sociobiology, 54: 243-267.

Oliveira-Filho AT, Fontes MAL. 2000. Patterns of floristic differentiation among Atlantic forests in Southeastern Brazil and the influence of climate. Biotropica, 32: 793-810.

Prance, G.T. 1973. Phytogeographic support for the theory of Pleistocene forest refuges in the Amazon basin based on evidence from distribution patterns in Caryocaraceae, Chrysobalanaceae, Dichapetalaceae and Lecythidaceae. Acta Amazonica, 3: 5-28.

Richards, O.W. 1978. The social wasps of the Americas excluding the Vespinae. British Museum (Natural History), London, 580p.

Santos, G.M. de M.; Aguiar, C.M.L.; Mello, M.A.R. 2010. Flower-visiting guild associated with the Caatinga flora: trophic interaction networks formed by social bees and social wasps with plants. Apidologie, 41: 466-475.

Salimon, C.I.; Brown, I.F. 2000. Secondary forest in western Amazonia: significant sinks for carbon released from deforestation? Interciencia, 25: 198-202.

Sigrist, M.S.; Carvalho, C.J.B. 2009. Historical relationships among areas of endemism in the tropical South America using Brooks Parsimony Analysis. Biota Neotropica, 9: 79-90.

Silveira, M. 2005. A floresta aberta com bambu no sudoeste da Amazônia: padröes e processos emmúltiplas escalas. EDUFAC, Rio Branco, 157p.

Silveira, M.; de Paula, N.M.C.; Brown, I.F.; Borges, H.B.N.; Daly. D.; Ferreira, L.A. 1997. Os 'buracos negros' da diversidade. CiênciaHoje, 22: 64-65.

Silveira, O.T. 2002. Surveying neotropical social wasps. An evaluation of methods in the "Ferreira Penna" Research Station (ECFPn), in Caxiuanã, PA, Brazil (Hym.,Vespidae, Polistinae). PapéisAvulsos de Zoologia, 42: 299-323.
Silveira, L.F.; Beisiegel, B.M.; Curcio, F.F.; Valdujo, P.H.; Dixo, M.; Verdade, V.K; Mattox, G.M.T.; Cunningham, P.T.M. 2010. What use do fauna inventories serve? Estudos Avançados, 24:173-207.

Smithsonian Institution. 2017. Numbers of Insects (Species and Individuals). BugInfo. Smithsonian Institution. (https://www. si.edu/spotlight/buginfo/bugnos). Accessed on 05/10/2017.

Somvilla, A.; Oliveira, M.L.; Silveira, O.T. 2014. Diversity and aspects of the ecology of social wasps (Vespidae, Polistinae) in Central Amazonian 'terra firme' forest. Revista Brasileira de Entomologia, 58: 349 - 355.

Souza, M.B.; Silveira, M.; Lopes, M.R.M.; Vieira, L.J.S.; Guilherme, E.; Calouro, A.M.; Morato, E.F.2003. A biodiversidade no Estado do Acre: conhecimento atual, conservaçáo e perspectivas. T\& C Amazônia, 1: 45-56.

Storck-Tonon, D.; Morato, E.F.; de Melo, A.W.F.; Oliveira, M.L. 2013. Orchid bees of forest fragments in Southwestern Amazonia. Biota Neotropica, 13: 133-141.

Troudet, J.; Grandcolas, P.; Blin, A.; Vignes-Lebbe, R.; Legendre, F. 2017. Taxonomic bias in biodiversity data and societal preferences. Nature Scientific Reports, 7: 9132.

Vaz-de-Mello, F.Z. 1999. Scarabaeidae s.str. (Coleoptera, Scarabaeoidea) de um fragmento de floresta amazônica no Estado do Acre, Brasil. 1. Taxocenose. Anais da Sociedade Entomológica do Brasil, 28: 447-453.

Villarreal-Manzanilla, O.; Pinto-Da-Rocha, R. 2006. Five new species of Protimesius from Brazil (Opiliones: Stygnidae). Zootaxa, 1325: 219-233.

Whittaker, A.; Oren, D.C. 1999. Important ornithological records from the Rio Juruá, western Amazonian forest bird community. Bulletin of the British Ornithological Club, 119: 235-260.

Wilson, E.O. 1988. The current state of biological diversity. In: Wilson, E.O.; Peter, F.M. (Ed.). Biodiversity. Academic Press, Washington, p.3-18.

RECEIVED: $24 / 03 / 2017$

ACCEPTED: $10 / 11 / 2017$

ASSOCIATE EDITOR: Eraldo Rodrigues Lima 